\title{
India's science defended
}

SIR - Dr Malviya (Nature 306, 10; 1983) says that scientists in India are "not terribly science-minded" and that there is no competition among them. I imagine that, science being universal, "competition" ought to be among the scientists in the world rather than among those of a given country. And if one wishes to compete for recognition in science, one obviously ought to be science-minded.

I believe that Indian scientists working in India are not all that bad. During the past decade at least seven of them have been elected to the Royal Society of London, others as fellows of academies in the United States, the Soviet Union and in European countries while some hold high offices in international scientific unions and the like.

India is a vast heterogeneous nation with pockets of brilliance where the scientists are very good, and also many places of mediocrity, not strikingly different from the spectrum of the quality of Indian expatriates abroad: some very good and some mediocre.

On the hostility of Indian scientists towards their countrymen abroad, the Indian National Science Academy has about 30 of them as fellows in a total membership of some 500 , while the Indian Academy of Sciences, in its total fellowship of about 490 , has more than 30 Indians settled abroad. And we have not heard of any such hostility from the more than 100 expatriate Indian scientists (Dr Malviya included) who have visited our laboratory at our invitation in the past 2 years.

The question of improving the quality of Indian research necessarily involves the creation and generous support of centres of excellence and this infusion of new blood in its universities and research centres by the creation of additional research chairs with good salaries and facilities. The last idea has already been taken up in the form of a cadre of "research scientist" positions at existing universities. Such positions are open to both residents and expatriates, as they should be. No special consideration for expatriates seems to be necessary.

In considering how to improve the quality of scientific research in India, an appreciation of the existing efforts and problems is essential. Simplistic solutions or blanket condemnations are of no value. I am thus particularly dismayed at $\mathrm{Dr}$ Malviya's claim that the people who control science in India are scientifically most incompetent. Those concerned, many of them FRSs, include those who brought in the green (and now the white) revolution, who have put up Indian satellites and sent Indian research vessels to the Antarctic, set up nuclear plants for power production, trebled the amount of irrigation water in 30 years and controlled communicable diseases.

These scientists advise the central cabinet of ministers on scientific matters.
And it is this scientific competence, utilizing the science and technology base within, that has made India self-sufficient and not a market-place for giant multinational manufacturers.

Let us therefore not tie ourselves into knots of self-flagellation and also keep our temper - the scientific kind - so that we can attempt to solve our problems. (Incicidentally, the issue of Nature that carries Dr Malviya's letter also carries an article on the cloning of rice embryo histone genes by Indian scientists working in India.)

D.BALASUBRAMANIAN Centre for Cellular Molecular Biology, Hyderabad 500 007, India

\section{Who's playing God?}

SIR - In reviewing Paul Davies's God and the New Physics (Nature 305, 833; 1983) Professor McCrea eschews "any close critical assessment of the work". This approach is akin to that followed by most theologians and practising religionists; to construct elaborate hypotheses based on conjecture and wishful thinking and not squarely to examine the evidence.

While not discounting Dr Davies's scholasticism, it seems a bit over-stated for McCrea to experience "humility" in the light of Davies's "courageous thinking". How courageous must one be, in these times, to espouse ideas dating back to Epicurus? Davies, like many who have preceded him, is merely attempting to intellectualize and dilute the god-concept in order to make it more palatable to those emotionally-weak individuals whose educations would normally preclude such irrational ideas, but who are nonetheless attracted to Universe-schemes which give them a sense of value and purpose other than that which they are able to create for themselves.

This type of accommodation of science by religion has been repeatedly used by the Church throughout the ages in order for it to remain afloat in a sea of scepticism. Any definition of "God" which is interchangeable with "Universe" (another vague term) or "all in all" is completely useless both as a separate concept and as a source of meaning in human existence. Is it not better respectfully to retire such antiquated ideas?

In a decade when science and education are continually being undermined and assaulted by creationists and other pseudoscientists, it is high time that the scientific community should cease patronizing religion, which we have seen can be quite a formidable opponent to progress and the betterment of the human condition.

SCOTT A. KERNS

(Director, American Atheists, Houston Chapter)

Department of Microbiology, Baylor College of Medicine, Houston, Texas 77030, USA

\section{Inviable usage}

SIR - I share the concern indicated by Vimala Sarma, regarding the obfuscation in the recent report of the NH \& MRC of Australia, which has adopted a recommendation on rules for fetal research (Nature 306, 308; 1983).

Viable, which means capable of maintaining life, is an adjective which may be applied to the embryo, fetus or neonate; for, in the appropriate environment, each is indeed capable of maintaining its life, given adequate oxygen and nutrition, at least. "Previable" is a term which has no scientific basis, either in embryology or neonatology, to explain a given status of an embryo, fetus or neonate. The report itself indicates as much when it states - "dissection of the fetus should not be carried out while a heartbeat is'still apparent or there are other obvious signs of life".

This seems a clear case of scientific jargon obscuring meaning.

PATRICK W. GILL

Neath General Hospital,

Neath, Glamorgan SAII 2LQ, UK

\section{New words for old}

SIR - Your offer (Nature 306, 134; 1983) to make space available for comment on the abuse of language is welcome. I submit a plea that when new words are coined, they should be unambiguous. It is a pity that the pedantic rule against mixing languages is so often violated. Prebiotic may be cited as an example: probiotic or prevital are preferable.

Some words, for example, dyke and watershed, have antithetical meanings. In Britain, watershed means the line separating catchment areas, and that is the metaphorical meaning in the United States. When used non-metaphorically in the United States, it means a catchment area. So watershed is a meaningless word in an international journal. Chemical logic has introduced a few possibilities of ambiguity in written English, although context usually distinguishes the two meanings of such words as periodic and retinal.

Ambiguity could be avoided if editors took more care to correct the carelessness or ignorance of authors. As T.S. Eliot remarked: ". . . (words) slip, slide, perish, decay with imprecision ....". We are in danger of losing the distinction between enormity and enormousness, between militate and mitigate, and between suck and suckle (the baby sucks, the mother suckles). The original clearly defined meaning of visualize will be lost if the word is stretched to mean to stain or otherwise make visible. Perhaps another word is needed to carry that meaning - I suggest iconize or phanerize.

Rothamsted Experimental Station, N. W. PIRIE Harpenden, Herts AL5 2JO, UK 